Check for updates

Cite this: RSC Adv., 2018, 8, 6110

\title{
The promotion effect of manganese on Cu/SAPO for selective catalytic reduction of $\mathrm{NO}_{x}$ with $\mathrm{NH}_{3}$
}

\begin{abstract}
Chengkai Pang, (D) Yuqun Zhuo, ${ }^{*}$ Qiyu Weng and Zhenwu Zhu
The activity and hydrothermal stability of Cu/SAPO and $x \mathrm{Mn}-2 \mathrm{Cu} / \mathrm{SAPO}$ for low-temperature selective catalytic reduction of $\mathrm{NO}_{x}$ with ammonia were investigated. An ion-exchanged method was employed to synthesize $x \mathrm{Mn}-2 \mathrm{Cu} / \mathrm{SAPO}$, which was characterized by $\mathrm{N}_{2}$ adsorption, ICP-AES, $\mathrm{X}$-ray diffraction (XRD), $\mathrm{NH}_{3}$-temperature programmed desorption ( $\left.\mathrm{NH}_{3}-\mathrm{TPD}\right), \mathrm{NO}$ oxidation, $\mathrm{X}$-ray photoelectron spectrum (XPS), UV-vis, $\mathrm{H}_{2}$-temperature programmed reduction $\left(\mathrm{H}_{2}\right.$-TPR) and diffuse reflectance infrared Fourier transform spectra (DRIFTS). 2Mn-2Cu/SAPO and $4 \mathrm{Mn}-2 \mathrm{Cu} / \mathrm{SAPO}$ showed the best SCR activity, in that at $150{ }^{\circ} \mathrm{C}$ NO conversion reached $76 \%$ and $\mathrm{N}_{2}$ selectivity was above $95 \%$ for the samples. $\mathrm{NO}$ oxidation results showed that the $2 \mathrm{Mn}-2 \mathrm{Cu} / \mathrm{SAPO}$ had the best $\mathrm{NO}$ oxidation activity and the BET surface area decreased as manganese loading increased. XRD results showed that the metal species was well dispersed. $\mathrm{NH}_{3}$-TPD showed that the acid sites have no significant influence on the SCR activity of $x \mathrm{Mn}-2 \mathrm{Cu} / \mathrm{SAPO}$. $\mathrm{H}_{2}$-TPR patterns showed good redox capacity for $x \mathrm{Mn}-2 \mathrm{Cu} / \mathrm{SAPO}$. UV-vis and $\mathrm{H}_{2}$-TPR showed that the ratio of $\mathrm{Mn}^{4+}$ to $\mathrm{Mn}^{3+}$ increased as manganese loading increased. XPS spectra showed a significant amount of $\mathrm{Mn}^{3+}$ and $\mathrm{Mn}^{4+}$ species on the surface and addition of manganese increased the ratio of $\mathrm{Cu}^{2+}$. The promotion effect of manganese to $2 \mathrm{Cu} / \mathrm{SAPO}$ comes from the generation of $\mathrm{Mn}^{3+}$ and $\mathrm{Mn}^{4+}$ species. Deduced from the DRIFTS spectra, the Elay-Rideal mechanism was effective on $4 \mathrm{Mn}-2 \mathrm{Cu} / \mathrm{SAPO}$.
\end{abstract}

Received 11th November 2017 Accepted 23rd January 2018

DOI: $10.1039 / \mathrm{c} 7 \mathrm{ra12350g}$

rsc.li/rsc-advances a challenging task, especially for industrial applications such as cement plants or iron and steel plants, because the suitable process temperature for $\mathrm{NO}_{x}$ abatement is usually around $150{ }^{\circ} \mathrm{C}$, under which commercial SCR catalysts $\mathrm{V}_{2} \mathrm{O}_{5}-\mathrm{MoO}_{3}$ $\left(\mathrm{WO}_{3}\right) / \mathrm{TiO}_{2}$ cannot work well.

Manganese oxides were reported by Smirniotis et al. as potential catalysts for low-temperature $\mathrm{NH}_{3}$-SCR reactions. ${ }^{2-5}$ They studied the promoted manganese oxides supported on $\mathrm{TiO}_{2}$ systematically ${ }^{3-5}$ and found that the surface $\mathrm{Mn}^{4+}$ species was reported to be highly active for the SCR of NO reaction with ammonia at low temperatures.

Recently, copper modified zeolites with a CHA structure attracted much attention owing to their excellent activity, $\mathrm{N}_{2}$ selectivity and hydrothermal stability for low temperature $\mathrm{NH}_{3}$-SCR reaction. ${ }^{6-8}$

However for the $\mathrm{Cu} / \mathrm{SAPO}-34$ catalyst, the oxygen activation of transiently formed $\mathrm{Cu}$ pairs $\left[\mathrm{Cu}^{\mathrm{I}}\left(\mathrm{NH}_{3}\right)_{2}\right]$ to $\left[\left(\mathrm{NH}_{3}\right)_{2} \mathrm{Cu}^{\mathrm{II}}-\mathrm{O}_{2}\right.$ $\left.\mathrm{Cu}^{\mathrm{II}}\left(\mathrm{NH}_{3}\right)_{2}\right]$ was rate-limiting in the catalytic cycle. ${ }^{8}$ Feng $\mathrm{GaO}^{9}$ also thought that the oxidation reaction of $\mathrm{Cu}^{+}$to $\mathrm{Cu}^{2+}$ was the rate-determine step, so tuning the redox properties of the active site by introducing a second cation might be a promising approach. Li et al. ${ }^{10}$ and Chen et al. ${ }^{11}$ modified the Cu/SAPO catalyst with $\mathrm{CeO}_{x}$ for SCR reaction; they found that the introduction of $\mathrm{CeO}_{x}$ increased the SCR activity at high temperatures and cerium helped increase the amount of isolated $\mathrm{Cu}^{2+}$ ions.

Leistner $e$ al. ${ }^{12}$ found that $\mathrm{Cu}$ in $\mathrm{Cu} / \mathrm{SAPO}-34$ was more easily reduced compared to $\mathrm{Cu} / \mathrm{SSZ}-13$, which could facilitate the 
redox processes and increase the SCR activity. Ma et al. ${ }^{13}$ also found that Cu-SAPO-34 showed higher $\mathrm{DeNO}_{x}$ catalytic activity than Cu-SSZ-13. The usage of SAPO-34 in low-temperature SCR might be favored in low temperature SCR reactions. When manganese is introduced into the $\mathrm{Cu} / \mathrm{SAPO}$ system, it not only promotes the oxidation reaction of $\mathrm{Cu}^{+}$, but also acts as an active site for low temperature SCR reaction. Thus the manganese modified $\mathrm{Cu} / \mathrm{SAPO}-34$ catalyst would probably show better SCR activity.

In this work, the treatment of exhaust from a gas-fired boiler which contains a high concentration of $\mathrm{H}_{2} \mathrm{O}$ and a very low concentration of $\mathrm{SO}_{2}$ was focused upon. $x \mathrm{Mn}-\mathrm{Cu} / \mathrm{SAPO}$ catalysts with different manganese loadings were prepared and their performance in SCR reaction was discussed. Various characterization methods (XRD, XPS, $\mathrm{H}_{2}$-TPR, UV-vis) were used to probe the promotion effect of manganese on $\mathrm{Cu} / \mathrm{SAPO}$ for low temperature SCR reaction.

\section{Experimental}

\subsection{Catalyst preparation}

$x \mathrm{Mn}-2 \mathrm{Cu} / \mathrm{SAPO}$ catalysts were prepared by an ion-exchange method. The alkali metals in commercial Na/SAPO-34 powder (Jiangsu XFNANO) would decrease SCR activities, so it was transformed to $\mathrm{H}^{+} / \mathrm{SAPO}$ as follows. Na/SAPO-34 powder was ion exchanged using $11 \%$ wt $\mathrm{NH}_{4} \mathrm{NO}_{3}$ (Aladdin, $>98.5 \%$ ) solution whose $\mathrm{pH}$ value was adjusted to 3.0-4.0 by $2 \mathrm{M}$ ammonium hydroxide (Aladdin, 25-28\%) solution at $80{ }^{\circ} \mathrm{C}$ for $4 \mathrm{~h}$. It was then filtered and washed with distilled water three times. Finally, it was dried at $110{ }^{\circ} \mathrm{C}$ for $16 \mathrm{~h}$ and calcined at $550{ }^{\circ} \mathrm{C}$ for $3 \mathrm{~h}$.

$x \mathrm{Mn}-2 \mathrm{Cu} / \mathrm{SAPO}(x=0,1,2,4,8)$ was prepared in two steps. Firstly, $\mathrm{H}^{+} / \mathrm{SAPO}$ was mixed with $\mathrm{Cu}\left(\mathrm{NO}_{3}\right)_{2}$ (across, >95\%) solution at $80{ }^{\circ} \mathrm{C}$ for $6 \mathrm{~h}$ under vigorous stirring. Then it was dried and calcined at $550{ }^{\circ} \mathrm{C}$ for $3 \mathrm{~h}$. In the second step, it was mixed with $\mathrm{Mn}\left(\mathrm{NO}_{3}\right)_{2}$ (across, $>95 \%$ ) solution at $80{ }^{\circ} \mathrm{C}$ for $6 \mathrm{~h}$ under vigorous stirring, and at last it was dried and calcined at $550{ }^{\circ} \mathrm{C}$ for $3 \mathrm{~h}$.

\subsection{SCR activity measurements}

Catalytic activity evaluation was carried out using a flowthrough powder reactor system equipped with a Fourier transform infrared (FT-IR) spectrometer (THERMO SCIENTIFIC IGS). In order to prevent condensation along upstream tubing, all the gas lines were heated and maintained at $120{ }^{\circ} \mathrm{C}$. The gas mixture was $500 \mathrm{ppm} \mathrm{NO}+500 \mathrm{ppm} \mathrm{NH}_{3}+3 \%$ vol $\mathrm{O}_{2}$ balanced with $\mathrm{N}_{2}$. The gas hourly space velocity (GHSV) was $65000 \mathrm{~h}^{-1}$ for the standard SCR reaction. Prior to each activity measurement, the catalysts were pretreated at $500{ }^{\circ} \mathrm{C}$ for $30 \mathrm{~min}$ with $21 \% \mathrm{vol}$ $\mathrm{O}_{2} / \mathrm{N}_{2}$ flow. Catalytic activities were measured in the temperature range of 120 to $210{ }^{\circ} \mathrm{C}$. The typical time to achieve the steady state was $2.5 \mathrm{~h}$. NO conversion, promotion effect, and $\left(E_{\mathrm{p}}\right)$ and $\mathrm{N}_{2}$ selectivity were calculated at steady state using the equation below:

$$
X_{\mathrm{NO}}=\frac{C_{\mathrm{NO}_{x \text { in }}}-C_{\mathrm{NO}_{x \text { out }}}}{C_{\mathrm{NO} \text { in }}} \times 100 \%
$$

$$
\begin{gathered}
E_{\mathrm{p}}=\left(X_{x \mathrm{Mn}-2 \mathrm{Cu} / \mathrm{SAPO}}-X_{2 \mathrm{Cu} / \mathrm{SAPO}}\right) \times 100 \% \\
\mathrm{~N}_{2} \text { selectivity }=\left(1-\frac{2\left[\mathrm{~N}_{2} \mathrm{O}\right]_{\text {outlet }}}{\left[\mathrm{NO}_{x}\right]_{\text {inlet }}-\left[\mathrm{NO}_{x}\right]_{\text {outlet }}}\right) \times 100 \%
\end{gathered}
$$

where $C_{\mathrm{NO} x}$ in and $C_{\mathrm{NO} x \text { out }}$ represent the inlet and outlet $\mathrm{NO}_{x}$ concentration. $X_{x \mathrm{Mn}-2 \mathrm{Cu} / \mathrm{SAPO}}, X_{2 \mathrm{Cu} / \mathrm{SAPO}}$ and $X_{x \mathrm{Mn} / \mathrm{SAPO}}$ respectively represent the $\mathrm{NO}_{x}$ conversion of $x \mathrm{Mn}-2 \mathrm{Cu} / \mathrm{SAPO}, 2 \mathrm{Cu}$ / SAPO and $x \mathrm{Mn} / \mathrm{SAPO}$ at $210{ }^{\circ} \mathrm{C}$, and $\left[\mathrm{N}_{2} \mathrm{O}\right]_{\text {outlet }}$ represents the outlet $\mathrm{N}_{2} \mathrm{O}$ concentration.

\subsection{Characterization}

$\mathrm{X}$-ray diffraction patterns were collected on a bruker D8 Advance $\mathrm{X}$-ray diffractometer with a Ni-Filtered $\mathrm{Cu} \mathrm{K} \alpha$ with a step size of 0.02 in the $2 \theta$ range of $5^{\circ}$ to $40^{\circ}$.

Ammonia temperature programmed desorption ( $\left.\mathrm{NH}_{3}-\mathrm{TPD}\right)$ experiments were carried out as follows. $150 \mathrm{mg}$ sample was first pretreated in $21 \%$ vol $\mathrm{O}_{2} / \mathrm{N}_{2}$ at $500{ }^{\circ} \mathrm{C}$ for $30 \mathrm{~min}$ and then cooled to $100{ }^{\circ} \mathrm{C}$ in $\mathrm{N}_{2}$ and a total flow of $100 \mathrm{ml} \mathrm{min}{ }^{-1}$ containing 2500 ppm $\mathrm{NH}_{3}$ in $\mathrm{N}_{2}$ was injected into the reactor for 2 hours to achieve a steady state. Once the catalyst was saturated, $\mathrm{NH}_{3}$ was switched off and the catalyst was swept by $\mathrm{N}_{2}$ overnight. Finally, the catalyst was heated in $\mathrm{N}_{2}$ at a temperature ramp to $700{ }^{\circ} \mathrm{C}$ with a heating rate of $10{ }^{\circ} \mathrm{C} \mathrm{min}^{-1}$.

NO oxidation experiments were carried out as follows. $150 \mathrm{mg}$ sample was first pretreated in $21 \%$ vol $\mathrm{O}_{2} / \mathrm{N}_{2}$ at $500{ }^{\circ} \mathrm{C}$ for $30 \mathrm{~min}$ and then cooled to $210{ }^{\circ} \mathrm{C}$ in $\mathrm{N}_{2}$. Then a total flow of $100 \mathrm{ml} \mathrm{min} \mathrm{min}^{-1}$ containing $500 \mathrm{ppm} \mathrm{NO}$ and $3 \%$ vol $\mathrm{O}_{2}$ was injected into the reactor for $30 \mathrm{~min}$ to achieve the steady state.

The contents of the elements were determined by ion coupled plasma (ICP) optical emission spectroscopy (Thermo IRIS Intrepid II) after microwave digestion.

The BET surface area, pore volume and pore size of the catalyst samples were measured by $\mathrm{N}_{2}$ adsorption using the MICROMERITICS ASAP 2020 surface area and porosity analyzer.

Diffuse reflectance UV-vis spectra were recorded in the range of 200-800 nm against a $\mathrm{BaSO}_{4}$ as a reference standard on a HitachiU-3900 UV-vis spectrophotometer equipped with an integration sphere.

$\mathrm{H}_{2}$-TPR experiments were performed using $20 \mathrm{mg}$ sample as follows. The catalysts were first pretreated at $500{ }^{\circ} \mathrm{C}$ for $30 \mathrm{~min}$ in a highly pure $\mathrm{O}_{2}\left(40 \mathrm{ml} \mathrm{min}{ }^{-1}\right)$ stream. Then the furnace temperature was decreased to room temperature, and feed containing $5 \%$ vol $\mathrm{H}_{2}$ in $\mathrm{N}_{2}$ was fed at a flow rate of $40 \mathrm{ml} \mathrm{min}^{-1}$. $\mathrm{H}_{2}$-TPR runs were performed as the temperature increased from room temperature to $800{ }^{\circ} \mathrm{C}$ at a linear heating rate of $10{ }^{\circ} \mathrm{C} \min ^{-1}$ and then the temperature was kept constant for $30 \mathrm{~min}$ at $800{ }^{\circ} \mathrm{C}$ to ensure complete reduction. Hydrogen was measured by TCD.

X-ray photoelectron spectroscopy (XPS) analyses were performed using PHI quantera SXM Scanning ESCA Microprobe (Physical Electronics) with a hemispherical detector operating at a constant pass energy $(\mathrm{PE}=55 \mathrm{eV})$. An X-ray source at $210 \mathrm{~W}$ $(I=15 \mathrm{~mA}, U=14 \mathrm{kV})$ and $\mathrm{Al} \mathrm{K} \alpha$ radiation $(1486.6 \mathrm{eV})$ were used. Intensities were estimated from the integration of each peak, after smoothening, subtracting the L-shaped background, 
and fitting the experimental curve to a combination of Lorentzian and Gaussian lines of variable proportions. All binding energies were referenced to the $\mathrm{C} 1 \mathrm{~s}$ line at $284.8 \mathrm{eV}$.

Diffuse reflectance infrared Fourier transform spectra (DRIFTS) were measured on an FT-IR spectrometer (Thermo Nicolet NEXUS870) with an MCT detector and high temperature reaction chamber (Harrick Scientific Praying Mantis) with ZnSe Windows, which was connected to a gas-dosing system. The powder sample was placed in a sample cup and heated by a cartridge heater underneath the sample. The temperature was adjusted using a K-type thermocouple connected to a Harrick temperature controller. Before each measurement, oxidation pretreatments were executed at $500{ }^{\circ} \mathrm{C}$ for $1 \mathrm{~h}$. Background spectra were collected before adsorption for 32 scans with a resolution of $4 \mathrm{~cm}^{-1}$ in $\mathrm{N}_{2}$. DRIFTS spectra were recorded in the range of $4000-650 \mathrm{~cm}^{-1}$ for 32 scans with a resolution of $4 \mathrm{~cm}^{-1}$.

\section{Results and discussion}

\subsection{Low temperature $\mathrm{NH}_{3}-\mathrm{SCR}$ activity and $\mathrm{N}_{2}$ selectivity}

Fig. 1a shows the NO conversion of $x \mathrm{Mn}-2 \mathrm{Cu} / \mathrm{SAPO}$. There was not much difference in the catalytic activity between $2 \mathrm{Cu} / \mathrm{SAPO}$ and $1 \mathrm{Mn}-2 \mathrm{Cu} / \mathrm{SAPO}, 2 \mathrm{Mn}-2 \mathrm{Cu} / \mathrm{SAPO}$ and $4 \mathrm{Mn}-2 \mathrm{Cu} / \mathrm{SAPO}$. The activity of $8 \mathrm{Mn}-2 \mathrm{Cu} / \mathrm{SAPO}$ was slightly lower than the activity of $2 \mathrm{Mn}-2 \mathrm{Cu} / \mathrm{SAPO}$. As manganese loading increased from $1 \%$ to $2 \%$, the activity increased obviously and the SCR activity of $2 \mathrm{Mn}-2 \mathrm{Cu} / \mathrm{SAPO}, 4 \mathrm{Mn}-2 \mathrm{Cu} / \mathrm{SAPO}$ and $8 \mathrm{Mn}-2 \mathrm{Cu} / \mathrm{SAPO}$ was much higher than that of $2 \mathrm{Cu} / \mathrm{SAPO}$ and $1 \mathrm{Mn}-2 \mathrm{Cu} / \mathrm{SAPO}$.

For $2 \mathrm{Mn}-2 \mathrm{Cu} / \mathrm{SAPO}$ and $4 \mathrm{Mn}-2 \mathrm{Cu} / \mathrm{SAPO}$, the conversion of $\mathrm{NO}$ at $120{ }^{\circ} \mathrm{C}$ was about $60 \%$; as the temperature increased to $210{ }^{\circ} \mathrm{C}$, the conversion reached $95 \%$.

Fig. 1b shows the $\mathrm{N}_{2}$ selectivity of $x \mathrm{Mn}-2 \mathrm{Cu} / \mathrm{SAPO}$. Good $\mathrm{N}_{2}$ selectivity was observed, being above $95 \%$ for all catalysts. Other researchers ${ }^{\mathbf{1 0 , 1 1}}$ also found good $\mathrm{N}_{2}$ selectivity for the supported SAPO-34 catalysts.

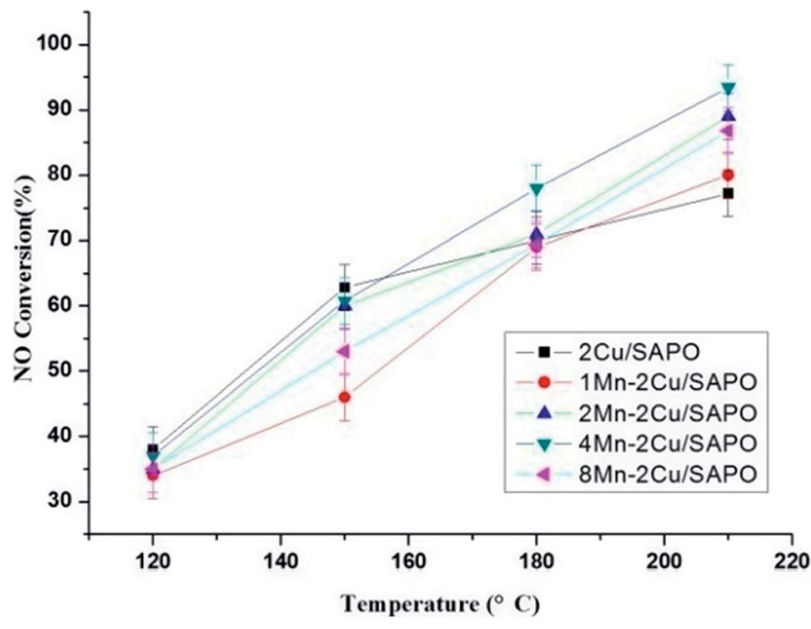

Fig. 2 Water resistance test of $x \mathrm{Mn}-2 \mathrm{Cu} / \mathrm{SAPO}$ for low-temperature SCR. Conditions: 500 ppm NO +500 ppm NH$H_{3}+16.3 \% \mathrm{H}_{2} \mathrm{O}+3 \%$ vol $\mathrm{O}_{2}+\mathrm{N}_{2}$ balance, $\mathrm{GHSV}=65000 \mathrm{~h}^{-1}$.

Compared with $x \mathrm{Mn} / \mathrm{SAPO}(x=1,2,4,8)$, the previously prepared, ${ }^{14} x \mathrm{Mn}-2 \mathrm{Cu} / \mathrm{SAPO}$ showed better SCR activities, especially for $2 \mathrm{MN}-2 \mathrm{Cu} / \mathrm{SAPO}$, indicating that the interactions between copper and manganese might increase its SCR activity.

\subsection{Water resistance test}

Fig. 2 shows the water resistance test of $x \mathrm{Mn}-2 \mathrm{Cu} / \mathrm{SAPO}$. The poison effect of water might come from the reversible adsorption of $\mathrm{H}_{2} \mathrm{O}^{15}$ or irreversible dealumination process of zeolite. ${ }^{16}$

In Fig. 2, all catalysts showed strong resistance to water at high temperature. It could be caused by the lower adsorption capability of water at high temperature, since SAPO-34 was highly hydrothermally stable ${ }^{16}$ and the poison effect might originate from the competitive adsorption of water with ammonia.
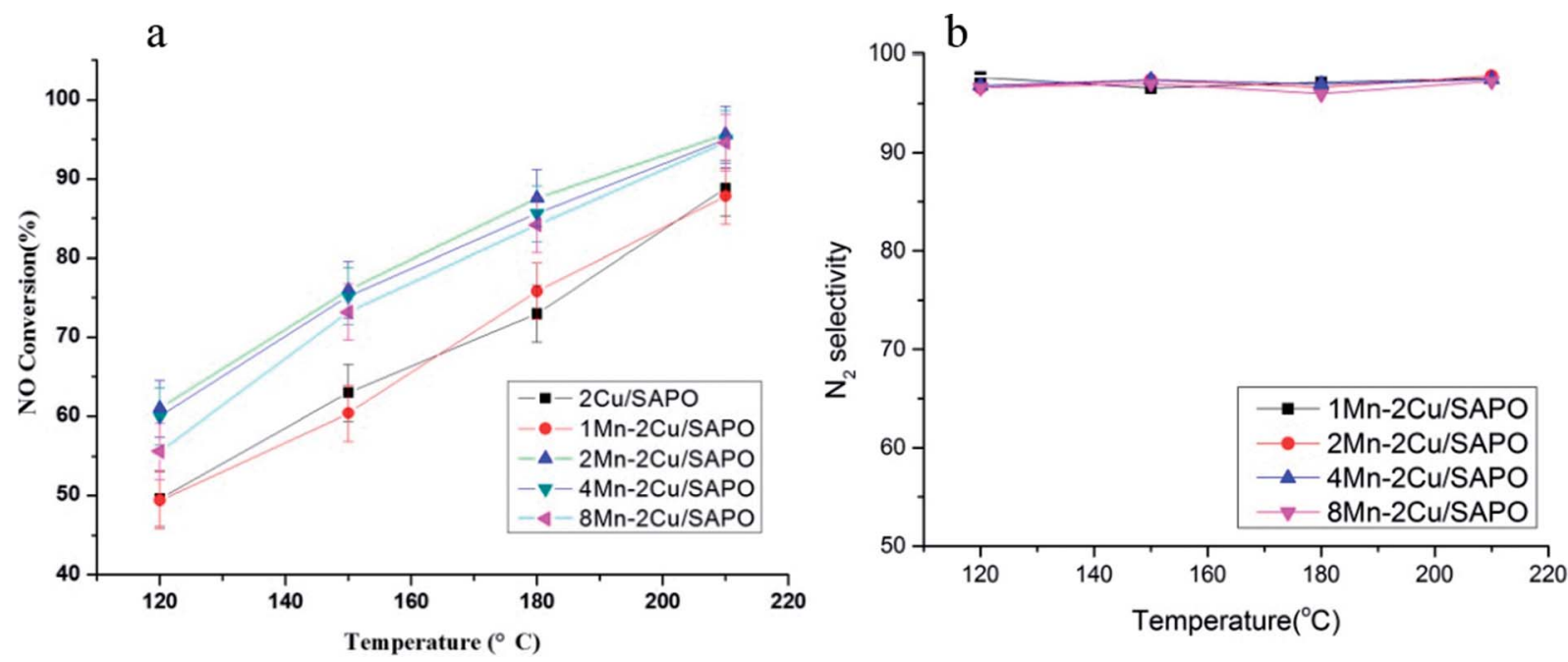

Fig. 1 (a) Catalytic activity and (b) $\mathrm{N}_{2}$ selectivity of $x \mathrm{Mn}-2 \mathrm{Cu} / \mathrm{SAPO}$. Conditions: $500 \mathrm{ppm} \mathrm{NO}+500$ ppm $\mathrm{NH}_{3}+3 \%$ vol $\mathrm{O}_{2}+\mathrm{N}_{2}$ balance, GHSV $=$ $65000 \mathrm{~h}^{-1}$. 


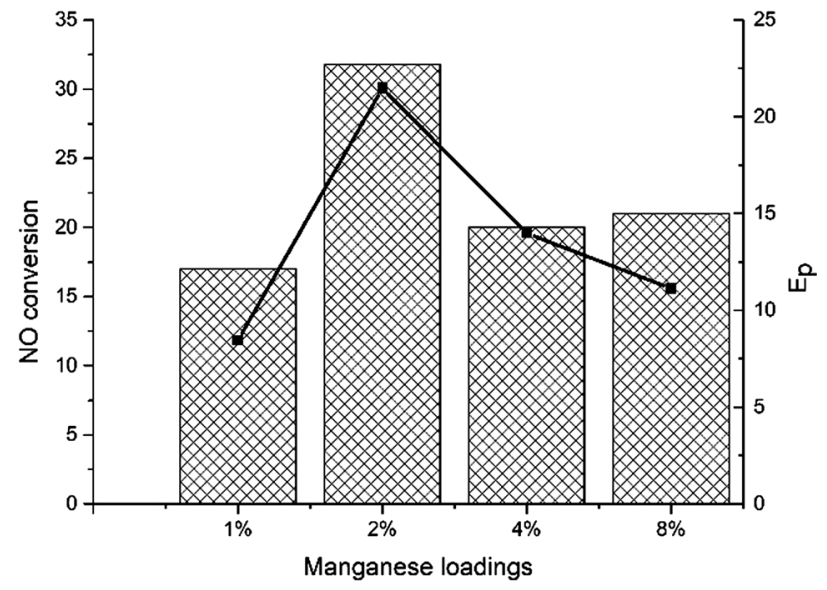

Fig. 3 NO oxidation activity and promotion effect of manganese.

\subsection{NO oxidation activity and promotion effect}

Fig. 3 showed the NO oxidation activity of $x \mathrm{Mn}-2 \mathrm{Cu} / \mathrm{SAPO}$ and the promotion effect. $2 \mathrm{Mn}-2 \mathrm{Cu} / \mathrm{SAPO}$ had the best NO oxidation activity, indicating the interaction between copper and manganese elements, which accelerated the NO oxidation process. Good oxidation activity would certainly help the oxidation of $\mathrm{Cu}^{+}$to $\mathrm{Cu}^{2+}$ in SCR reaction. The $E_{\mathrm{p}}$ profile was almost the same as the NO conversion profile, indicating that the increase in NO oxidation activity would promote the lowtemperature SCR activity. Compared with the $x \mathrm{Mn} / \mathrm{SAPO}(x=$ $1,2,4,8)$ previously prepared, ${ }^{\mathbf{1 4}}$ the NO oxidation activities of $x \mathrm{Mn}-2 \mathrm{Cu} / \mathrm{SAPO}$ were much higher, which could be one reason for the increased SCR activity.

\subsection{Physicochemical properties}

As showed in Table 1, the BET surface area and micro pore volume decreased gradually as manganese loading increased; the surface areas of $2 \mathrm{Mn}-2 \mathrm{Cu} / \mathrm{SAPO}, 4 \mathrm{Mn}-2 \mathrm{Cu} / \mathrm{SAPO}$ and $8 \mathrm{Mn}-$ $2 \mathrm{Cu} / \mathrm{SAPO}$ were similar. $x \mathrm{Mn} / \mathrm{SAPO}(x=1,2,4,8)$ previously prepared $^{\mathbf{1 4}}$ showed the same trend: the surface area and pore volume decreased as manganese loading increased.

The manganese loading, copper loading and $\mathrm{Mn} / \mathrm{Cu}$ molar ratio from ICP result were almost the same as the set values. Meanwhile the $\mathrm{Mn} / \mathrm{Cu}$ molar ratio from the XPS results was quite different from that of ICP results. Since XPS and ICP reflect the elemental information of the surface phase and the bulk phase respectively, the difference might come from the enrichment of manganese on surface.

\subsection{XRD}

$\mathrm{XRD}$ patterns of $x \mathrm{Mn}-2 \mathrm{Cu} / \mathrm{SAPO}$ are depicted in Fig. 4 . The diffraction peaks of chabazite phase with the space group of $R \overline{3} m$ were identified, indicating that the crystalline structure of SAPO-34 remained unchanged after catalyst preparation. When manganese loading increased from 0 to $4 \%$, only the chabazite phase was detectable, indicating that the manganese species were well dispersed. As manganese loading reached $8 \%$, the diffraction peaks of the $\mathrm{Mn}_{2} \mathrm{O}_{3}$ phase appeared, indicating the aggregation of manganese species and decreased manganese dispersity. On $x \mathrm{Mn}$ /SAPO $(x=1,2,4,8)$, which was previously prepared, ${ }^{\mathbf{1 4}}$ there too were no peaks attributed to manganese oxides until manganese loading increased to $8 \%$.

\section{6 $\mathrm{NH}_{3}$-TPD}

Fig. 5 showed the effluent $\mathrm{NH}_{3}$ profiles during the $\mathrm{NH}_{3}$-TPD process. The amount of $\mathrm{NH}_{3}$ desorption was closely related to the amount of acid sites. As expected, when manganese loading increased, the amount of $\mathrm{NH}_{3}$ desorption decreased, which was caused by the replacement of $\mathrm{H}^{+}$in the framework of SAPO by $\mathrm{Mn}^{x+}$ in the ion exchange process.

In Fig. 5 there are three $\mathrm{NH}_{3}$ desorption peaks, i.e. a low temperature peak at $250{ }^{\circ} \mathrm{C}$, a middle temperature peak at $400{ }^{\circ} \mathrm{C}$ and a high temperature peak at $500{ }^{\circ} \mathrm{C}$, which could be assigned to the weak acid site, the middle strong acid site and the strong acid site, respectively. ${ }^{17}$

The shapes of $1 \mathrm{Mn}-2 \mathrm{Cu} / \mathrm{SAPO}, 2 \mathrm{Mn}-2 \mathrm{Cu} / \mathrm{SAPO}$ and $4 \mathrm{Mn}-$ $2 \mathrm{Cu} / \mathrm{SAPO}$ were similar while the activity differed a lot, indicating that the related acid sites might not have significant influence on the SCR activity for $x \mathrm{Mn}-2 \mathrm{Cu} / \mathrm{SAPO}$. For $x \mathrm{Mn} /$ SAPO $(x=1,2,4,8),{ }^{14}$ the amount of ammonia desorption also decreased as manganese loading increased.

\section{7 $\mathrm{H}_{2}$-TPR}

The $\mathrm{H}_{2}$-TPR profiles of the four catalysts are depicted in Fig. 6 . For $8 \mathrm{Mn}-2 \mathrm{Cu} / \mathrm{SAPO}$, there were two sharp peaks at $278^{\circ} \mathrm{C}$ and $327{ }^{\circ} \mathrm{C}$, respectively. The former indicated the reduction of $\mathrm{MnO}_{2}$ to $\mathrm{Mn}_{2} \mathrm{O}_{3}$, while the latter indicated the reduction of $\mathrm{Mn}_{2} \mathrm{O}_{3}$ to $\mathrm{Mn}_{3} \mathrm{O}_{4} \cdot{ }^{3}$ Compared with $\mathrm{Mn} / \mathrm{TiO}_{2},{ }^{18,19}$ the reduction peaks moved to a lower temperature, indicating its good redox capacity.

Table 1 Physico-chemical properties

\begin{tabular}{|c|c|c|c|c|c|c|c|}
\hline Sample & $\begin{array}{l}\text { BET surface area } \\
\left(\mathrm{m}^{2} \mathrm{~g}^{-1}\right)\end{array}$ & $\begin{array}{l}\text { Micro pore volume } \\
\left(\mathrm{cm}^{3} \mathrm{~g}^{-1}\right)\end{array}$ & $\begin{array}{l}\text { Micro pore } \\
\text { width }(\mathrm{nm})\end{array}$ & $\begin{array}{l}\text { Mn loading } \\
\text { (wt } \%)\end{array}$ & $\begin{array}{l}\text { Cu loading }{ }^{a} \\
\text { (wt } \%)\end{array}$ & $\begin{array}{l}\mathrm{Mn} / \mathrm{Cu} \\
\text { molar ratio }^{a}\end{array}$ & $\begin{array}{l}\mathrm{Mn} / \mathrm{Cu} \\
\text { molar ratio }^{b}\end{array}$ \\
\hline $2 \mathrm{Cu} / \mathrm{SAPO}$ & 467 & 0.231 & 2.36 & & 1.951 & & \\
\hline $1 \mathrm{Mn}-2 \mathrm{Cu} / \mathrm{SAPO}$ & 459 & 0.230 & 1.90 & 1.054 & 2.016 & 0.51 & 1.587 \\
\hline $2 \mathrm{Mn}-2 \mathrm{Cu} / \mathrm{SAPO}$ & 430 & 0.228 & 2.53 & 2.108 & 1.998 & 1.055 & 2.594 \\
\hline $4 \mathrm{Mn}-2 \mathrm{Cu} / \mathrm{SAPO}$ & 426 & 0.206 & 1.96 & 3.846 & 2.048 & 1.878 & 3.424 \\
\hline $8 \mathrm{Mn}-2 \mathrm{Cu} / \mathrm{SAPO}$ & 424 & 0.196 & 2.54 & 8.306 & 1.848 & 4.495 & 9.104 \\
\hline
\end{tabular}

${ }^{a}$ Determined by ICP. ${ }^{b}$ Determined by XPS. 


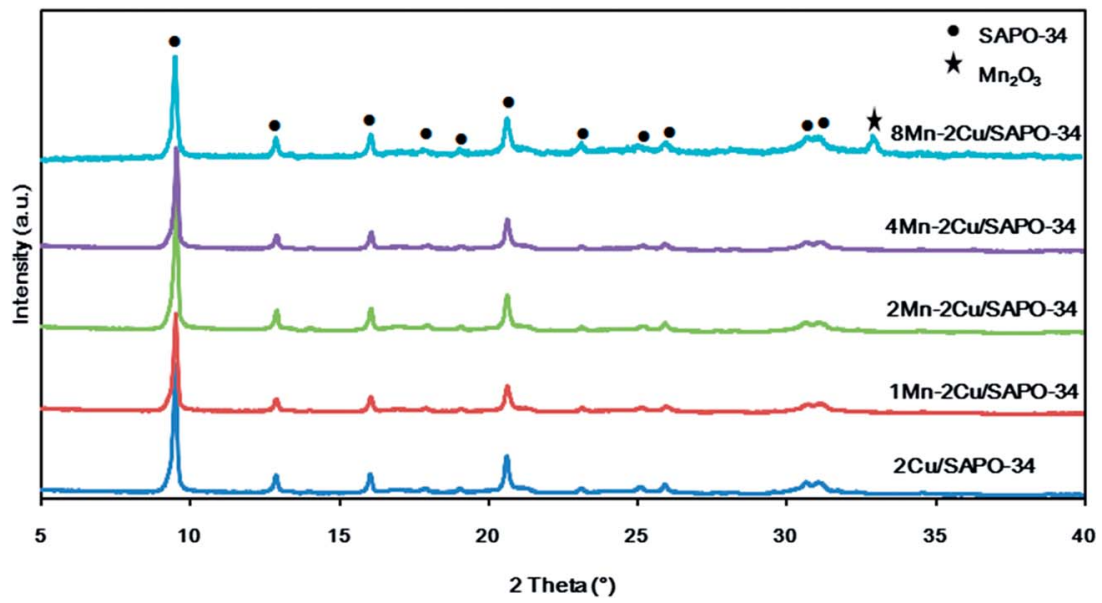

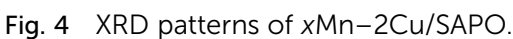

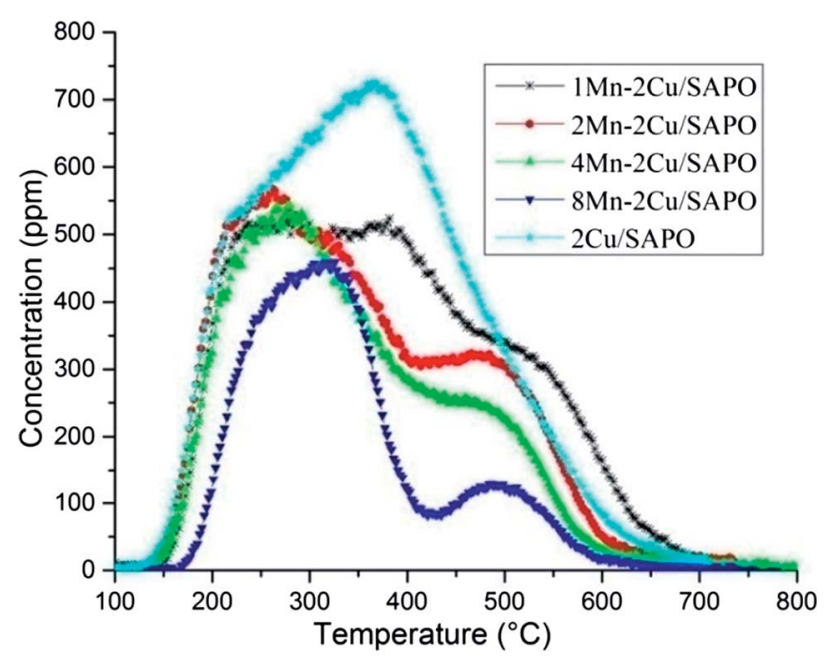

Fig. $5 \mathrm{NH}_{3}-\mathrm{TPD}$ of $x \mathrm{Mn}-2 \mathrm{Cu} / \mathrm{SAPO}$.

In the TPR patterns, the reduction process of copper in SAPO-34 zeolite could be separated into two steps, i.e. the reduction of $\mathrm{Cu}^{2+}$ to $\mathrm{Cu}^{+}$at about $300{ }^{\circ} \mathrm{C}$ and the reduction of $\mathrm{Cu}^{+}$to $\mathrm{Cu}^{0}$ at about $440{ }^{\circ} \mathrm{C},{ }^{10}$ while in Fig. 6 the peak strength of $1 \mathrm{Mn}-2 \mathrm{Cu} / \mathrm{SAPO}$ was relatively low, indicating that the peak strength of $2 \mathrm{Cu} / \mathrm{SAPO}$ was even lower, making the assignation of copper species difficult and unreasonable, so the assignation of copper was not discussed. The hydrogen consumption amount of copper reduction was relatively low, so the ignorance of copper species would not influence the discussion of manganese species.

As manganese loading increased, the peaks at $278{ }^{\circ} \mathrm{C}$ and $327{ }^{\circ} \mathrm{C}$ increased, indicating that the proportion of $\mathrm{Mn}^{3+}$ and $\mathrm{Mn}^{4+}$ species increased. For $1 \mathrm{Mn}-2 \mathrm{Cu} / \mathrm{SAPO}$ catalysts, only one broad peak between 250 and $400{ }^{\circ} \mathrm{C}$ was detectable, indicating that most of the manganese species were $\mathrm{Mn}^{2+}$ since $\mathrm{Mn}^{2+}$ cannot be reduced below $700{ }^{\circ} \mathrm{C}$. Since $\mathrm{Mn}^{2+}$ species were inactive for SCR reaction, addition of manganese did not help increase the activity for $1 \mathrm{Mn}-2 \mathrm{Cu} / \mathrm{SAPO}$, which was consistent with $E_{\mathrm{p}}$ trends and NO oxidation results. For $2 \mathrm{Mn}-2 \mathrm{Cu} / \mathrm{SAPO}$ the peaks belonging to $\mathrm{Mn}^{3+}$ and $\mathrm{Mn}^{4+}$ species started to generate, indicating its good redox capacity. For $4 \mathrm{Mn}-2 \mathrm{Cu}$ / SAPO and $8 \mathrm{Mn}-2 \mathrm{Cu} / \mathrm{SAPO}$, the peaks at $278{ }^{\circ} \mathrm{C}$ and $327{ }^{\circ} \mathrm{C}$ increased greatly, indicating that the ratio of $\mathrm{Mn}^{3+}$ and $\mathrm{Mn}^{4+}$ increased. When manganese loading was above $2 \%, \mathrm{Mn}^{3+}$ and $\mathrm{Mn}^{4+}$ species began to generate, which is consistent with the $E_{\mathrm{p}}$ trends and NO oxidation results.

Compared with $x \mathrm{Mn} / \mathrm{SAPO}(x=1,2,4,8)$ previously prepared, ${ }^{14}$ for which the temperature peak of $\mathrm{H}_{2}$-TPR was about $353^{\circ} \mathrm{C}$ and $442{ }^{\circ} \mathrm{C}$, the peak temperature moved to a lower value, indicating that the interactions between copper and manganese species might accelerate oxidation reaction and increase the catalytic oxidation activity, which would promote low temperature SCR reaction.

Table 2 represents the hydrogen consumption of $x \mathrm{Mn}-2 \mathrm{Cu} /$ SAPO during TPR processes. As manganese loading increased, hydrogen consumption increased gradually, while the actual hydrogen consumption was much lower than the theoretical value. The ratio of experimental hydrogen consumption to

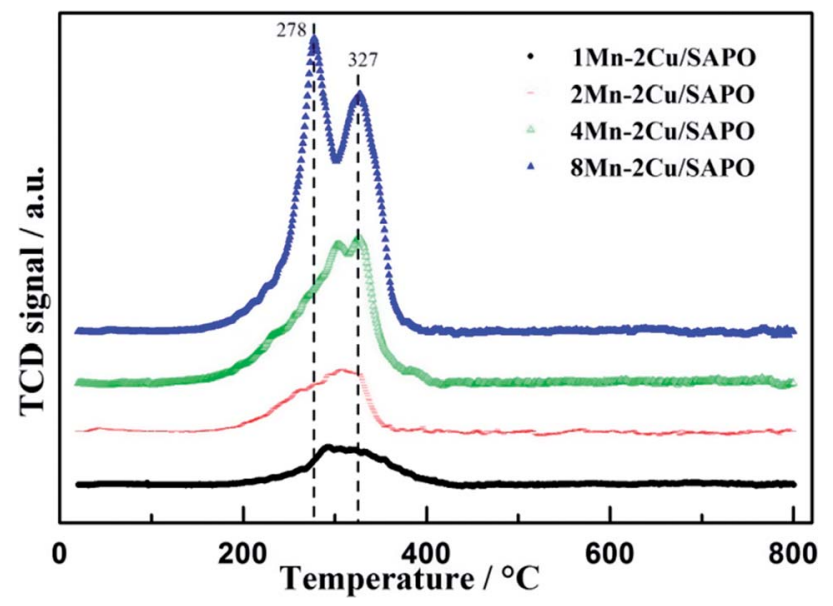

Fig. $6 \mathrm{H}_{2}$-TPR of $x \mathrm{Mn}-2 \mathrm{Cu} / \mathrm{SAPO}$. 
Table 2 Hydrogen consumption

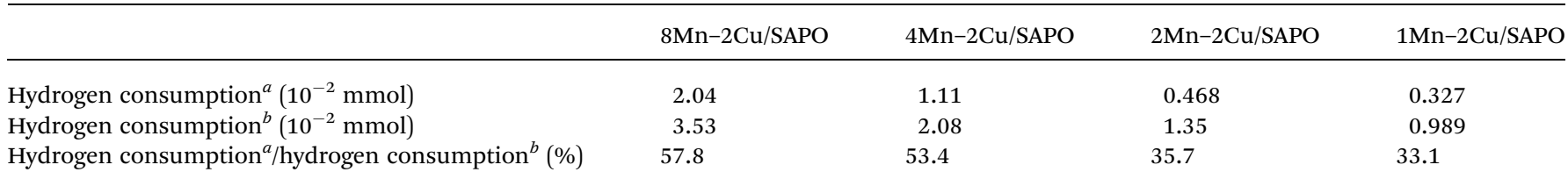

${ }^{a}$ The actual hydrogen consumption calculated from TPR profiles. ${ }^{b}$ The theoretical hydrogen consumption, assuming all of the $\mathrm{Cu}$ species are $\mathrm{Cu}^{2+}$ and reduced to $\mathrm{Cu}^{0}$, and all of the $\mathrm{Mn}$ species are $\mathrm{Mn}^{4+}$ and reduced to $\mathrm{Mn}^{2+}$ in TPR process.

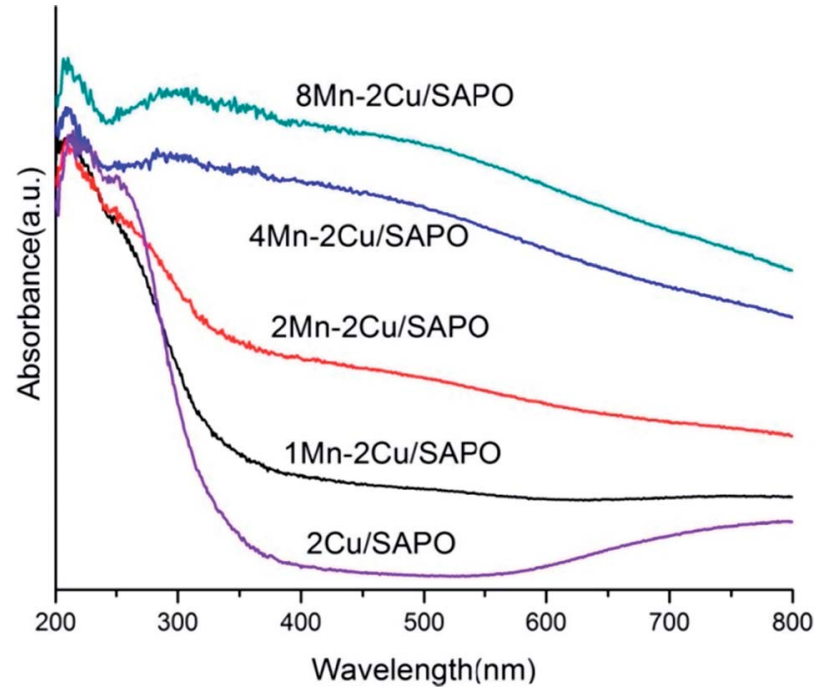

Fig. 7 DR UV-vis spectra recorded under ambient atmosphere of $x M n-2 C u / S A P O$.

theoretical hydrogen consumption of $8 \mathrm{Mn}-2 \mathrm{Cu} / \mathrm{SAPO}$ and $4 \mathrm{Mn}-2 \mathrm{Cu} / \mathrm{SAPO}$ was similar, as well as that of $1 \mathrm{Mn}-2 \mathrm{Cu} / \mathrm{SAPO}$ and $2 \mathrm{Mn}-2 \mathrm{Cu} / \mathrm{SAPO}$. Since the ratio of experimental hydrogen consumption to theoretical hydrogen consumption was highly related to the proportion of $\mathrm{Mn}^{3+}$ and $\mathrm{Mn}^{4+}$, the proportion of $\mathrm{Mn}^{3+}$ and $\mathrm{Mn}^{4+}$ for $1 \mathrm{Mn}-2 \mathrm{Cu} / \mathrm{SAPO}$ and $2 \mathrm{Mn}-2 \mathrm{Cu} / \mathrm{SAPO}$ were similar, as well as that of $8 \mathrm{Mn}-2 \mathrm{Cu} / \mathrm{SAPO}$ and $4 \mathrm{Mn}-2 \mathrm{Cu} / \mathrm{SAPO}$.

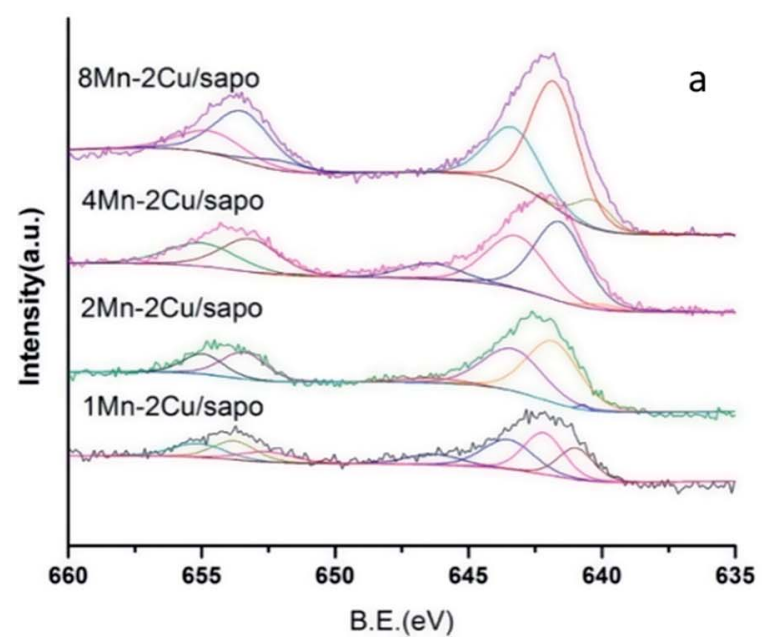

Fig. 8 XPS spectra of (a) Mn 2P and (b) Cu 2P.

\subsection{DR UV-vis}

The UV-vis spectra of the samples are given in Fig. 7. In Fig. 7, the absorption bands at $240 \mathrm{~nm}$ were related to the charge transfer processes between the framework aluminum and oxygen atoms of aluminophosphate..$^{20}$ The band at $220 \mathrm{~nm}$ was attributed to the oxygen-to-metal charge-transfer of the isolated $\mathrm{Cu}^{+} / \mathrm{Cu}^{2+}$ bound on the framework of zeolites. ${ }^{21,22}$ The bands at 280-300 $\mathrm{nm}$ were assigned to copper oxide clusters. ${ }^{23,24}$ The bands at $700-800 \mathrm{~nm}$ were assigned to the $\mathrm{d}-\mathrm{d}$ transition of isolated $\mathrm{Cu}^{2+}$ in weak disordered octahedral coordination of Ocontaining ligands. ${ }^{23,25}$

The broad bands in the range $320-380 \mathrm{~nm}$ were attributed to the $\mathrm{Mn}^{3+} \leftarrow \mathrm{O}^{2-}$ charge transfer transition superimposed on the ${ }^{5} \mathrm{~B}_{1 \mathrm{~g}} \rightarrow{ }^{5} \mathrm{~B}_{2 \mathrm{~g}}$ crystal field $\mathrm{d}-\mathrm{d}$ transition. ${ }^{26}$ The band at $322 \mathrm{~nm}$ was tentatively assigned to the $\mathrm{Mn}^{3+} \leftarrow \mathrm{O}^{2-}$ charge transfer in $\mathrm{Mn}_{3} \mathrm{O}_{4}$ in which manganese was octahedrally coordinated with oxygen..$^{27-29}$ The band at $255-276 \mathrm{~nm}$ could be assigned to the $\mathrm{Mn}^{2+} \leftarrow \mathrm{O}^{2-}$ charge transfer transition in tetrahedral oxygen coordination. ${ }^{27,28}$ In the $\alpha-\mathrm{Mn}_{2} \mathrm{O}_{3}$ structure, $\mathrm{Mn}^{3+}$ ions occupied octahedral sites and, if highly symmetric, a single spin-allowed absorption band in the $\mathrm{d}-\mathrm{d}$ transition region was expected similarly to $\left[\mathrm{Mn}\left(\mathrm{H}_{2} \mathrm{O}\right)_{6}\right]^{3+}$ at $500 \mathrm{~nm}$.

As manganese loading increased, the band at $320-380 \mathrm{~nm}$ increased gradually especially when the manganese loading changed from $2 \%$ to $4 \%$, indicating that the percentage of $\mathrm{Mn}^{3+}$ increased.

Meanwhile the bands at $255-276 \mathrm{~nm}$ were generated, indicating that the percentage of $\mathrm{Mn}^{2+}$ decreased. Consistent with 
Table 3 Binding energies $(\mathrm{eV})$ of $\mathrm{Mn}^{x+} 2 \mathrm{P}_{3 / 2}$ and the percentage of $\mathrm{Mn}^{\mathrm{x+}}$

\begin{tabular}{llllllllll}
\hline & $\mathrm{Mn}^{2+}$ & & & $\mathrm{Mn}^{3+}$ & & & $\mathrm{Mn}^{4+}$ & \\
\cline { 2 - 3 } Compound & Peak $(\mathrm{eV})$ & $\%$ & & Peak $(\mathrm{eV})$ & $\%$ & & Peak $(\mathrm{eV})$ & $\%$ \\
\hline 1Mn-2Cu/SAPO & 640.97 & 26.3 & 642.19 & 38.8 & 643.51 & 34.9 \\
$2 \mathrm{Mn}-2 \mathrm{Cu} / \mathrm{SAPO}$ & 640.69 & 0.5 & 641.83 & 55.8 & 643.36 & 44.2 \\
$4 \mathrm{Mn}-2 \mathrm{Cu} / \mathrm{SAPO}$ & 639.99 & 0.1 & 641.58 & 56.2 & 643.18 & 43.8 \\
$8 \mathrm{Mn}-2 \mathrm{Cu} / \mathrm{SAPO}$ & 640.42 & 9.0 & 641.83 & 60.7 & 643.44 & 30.3 \\
\hline
\end{tabular}

Table 4 Binding energies (eV) of $\mathrm{Cu}^{x+} 2 \mathrm{P}_{3 / 2}$ and the percentage of $\mathrm{Cu}^{x+}$

\begin{tabular}{llllll}
\hline & \multicolumn{2}{ll}{$\mathrm{Cu}^{+}$} & & \multicolumn{2}{l}{$\mathrm{Cu}^{2+}$} \\
Compound & Peak $(\mathrm{eV})$ & $\%$ & & Peak $(\mathrm{eV})$ & $\%$ \\
\hline $2 \mathrm{Cu} / \mathrm{SAPO}$ & 932.75 & 78.3 & & 934.93 & 21.7 \\
$1 \mathrm{Mn}-2 \mathrm{Cu} / \mathrm{SAPO}$ & 932.75 & 79.9 & & 934.81 & 20.1 \\
$2 \mathrm{Mn}-2 \mathrm{Cu} / \mathrm{SAPO}$ & 932.64 & 75.6 & & 934.56 & 24.4 \\
$4 \mathrm{Mn}-2 \mathrm{Cu} / \mathrm{SAPO}$ & 932.84 & 65.7 & & 934.93 & 34.3 \\
$8 \mathrm{Mn}-2 \mathrm{Cu} / \mathrm{SAPO}$ & 932.82 & 67.2 & & 934.80 & 32.7 \\
& & & & &
\end{tabular}

the $\mathrm{H}_{2}$-TPR result, the UV-vis results showed the partial oxidation of $\mathrm{Mn}^{2+}$ to $\mathrm{Mn}^{3+}$ or $\mathrm{Mn}^{4+}$, when manganese loading increased.

The UV-vis spectra of $x \mathrm{Mn}-2 \mathrm{Cu} / \mathrm{SAPO}$ were similar to that of $x \mathrm{Mn} / \mathrm{SAPO}(x=1,2,4,8)^{14}$ in that the percentage of $\mathrm{Mn}^{3+}$ increased suddenly as manganese loading increased from $2 \%$ to $4 \%$, indicating that the distribution of manganese species might not have been influenced by the copper species.

\subsection{XPS}

Fig. 8a shows the XPS spectra of Mn $2 \mathrm{P}$ of $x \mathrm{Mn}-2 \mathrm{Cu} / \mathrm{SAPO}$. Two main peaks assigned respectively to $\mathrm{Mn} 2 \mathrm{P}_{3 / 2}$ at $642.5 \mathrm{eV}$ and Mn $2 \mathrm{P}_{1 / 2}$ at $654 \mathrm{eV}$ were observed.

By performing peak-fitting deconvolution, the $\mathrm{Mn} 2 \mathrm{P}_{3 / 2}$ peak could be separated into three peaks, i.e. $640.8-640.9 \mathrm{eV}, 642.1-$ 642.3 $\mathrm{eV}$ and 643.8-644.1 eV, which correspond to the $\mathrm{Mn}^{2+}$ species, $\mathrm{Mn}^{3+}$ species and $\mathrm{Mn}^{4+}$ species, ${ }^{3,30}$ respectively. The atomic percentages of manganese species in different valence states are shown in Table 3.

When manganese loading increased from $1 \%$ to $2 \%$, the percentage of $\mathrm{Mn}^{3+}$ and $\mathrm{Mn}^{4+}$ increased and the percentage of
$\mathrm{Mn}^{2+}$ decreased a lot, while when manganese loading kept increasing, the percentage of manganese species did not change much. This was consistent with the NO oxidation, $\mathrm{H}_{2}$ TPR and UV-vis results.

As manganese loading increased, the percentage of $\mathrm{Mn}^{3+}$ species increased, and the percentage of $\mathrm{Mn}^{4+}$ species also increased, except for $8 \mathrm{Mn}-2 \mathrm{Cu} / \mathrm{SAPO}$. This was consistent with the UV-vis and $\mathrm{H}_{2}$-TPR results. Though $\mathrm{H}_{2}$-TPR, UV-vis and XPS all showed that there were many $\mathrm{Mn}^{4+}$ and $\mathrm{Mn}^{3+}$ species on $8 \mathrm{Mn}-$ $2 \mathrm{Cu} / \mathrm{SAPO}$, the XRD patterns showed the $\mathrm{Mn}_{2} \mathrm{O}_{3}$ phase, which indicated the aggregation of manganese species and decreased manganese dispersity, and the $\mathrm{NH}_{3}$-TPD results showed that there were much less acid sites. The decreased manganese dispersity and the less acid sites could lead to the lower SCR activity. The XPS spectra of $x \mathrm{Mn} / \mathrm{SAPO}(x=1,2,4,8)^{14}$ also showed that most of the manganese species were $\mathrm{Mn}^{3+}$ and $\mathrm{Mn}^{4+}$.

Fig. $8 \mathrm{~b}$ shows the XPS spectra of $\mathrm{Cu} 2 \mathrm{P}$; two peaks respectively attributed to $\mathrm{Cu} 2 \mathrm{P}_{3 / 2}$ at $932.6 \mathrm{eV}$ and $\mathrm{Cu} 2 \mathrm{P}_{1 / 2}$ at $952.7 \mathrm{eV}$ were observed. The shake-up satellite was found at about $945 \mathrm{eV}$, indicating the presence of $\mathrm{Cu}^{2+}$ species. As manganese loading increased, the shake-up satellite increased, indicating that the amount of $\mathrm{Cu}^{2+}$ species increased.

By performing peak-fitting deconvolution, the $\mathrm{Cu} 2 \mathrm{P}_{3 / 2}$ peak could be separated into two peaks, at about $932.7 \mathrm{eV}$ and $934.8 \mathrm{eV}$ respectively, which was ascribed to the $\mathrm{Cu}^{+}$and $\mathrm{Cu}^{2+}$ species. ${ }^{31}$ The atom percentage of $\mathrm{Cu}^{+}$and $\mathrm{Cu}^{2+}$ is shown in Table 4. As manganese loading increased, the ratio of $\mathrm{Cu}^{2+}$ increased, indicating that the addition of manganese might oxidize $\mathrm{Cu}^{+}$into $\mathrm{Cu}^{2+}$, which was strong evidence that there was strong interaction between the copper and manganese species.

According to the results above and referring to the mechanism of SCR on $\mathrm{Cu} / \mathrm{SAPO}$ Feng $\mathrm{Gao}^{9}$ had put forward, the mechanism of SCR on $2 \mathrm{Mn}-2 \mathrm{Cu} / \mathrm{SAPO}$ could be proposed. Fig. 9 showed the proposed low temperature SCR mechanism on $2 \mathrm{Mn}-2 \mathrm{Cu} / \mathrm{SAPO}$. In the catalytic cycle, $\mathrm{Mn}^{x+}$ acts as a catalyst for the oxidation step of $\mathrm{Cu}^{+}$to $\mathrm{Cu}^{2+}$ in low temperature SCR reaction.

\subsection{DRIFTS}

In situ DRIFTS was performed to identify the adsorbed NO species. Fig. 10 shows the DRIFTS spectra of $4 \mathrm{Mn}-2 \mathrm{Cu} / \mathrm{SAPO}$ at $150{ }^{\circ} \mathrm{C}$ exposed to different gas phases. In Fig. 10a, there was only one positive band at $1360 \mathrm{~cm}^{-1}$ in the range of $1200-$

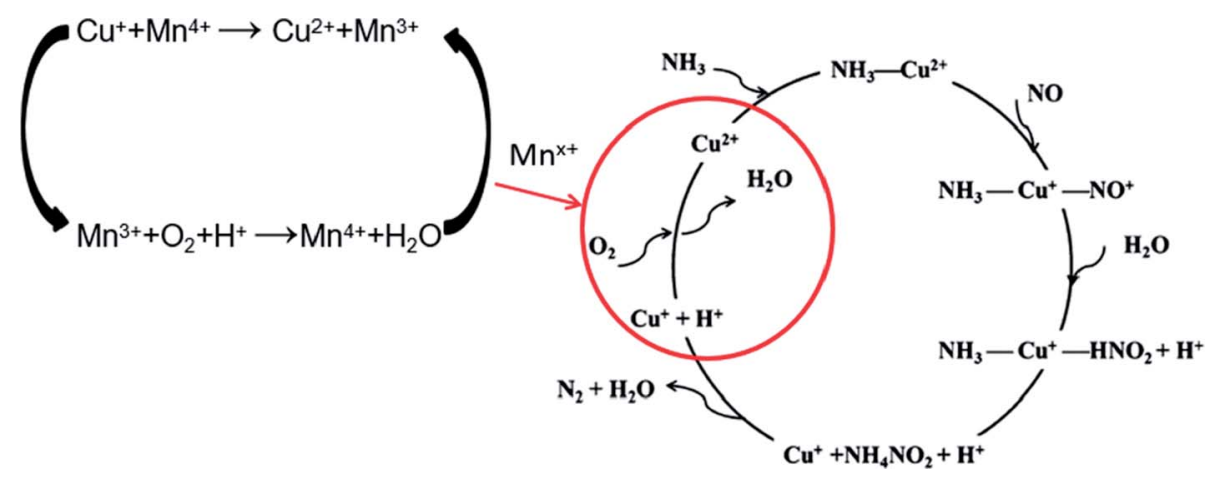

Fig. 9 The proposed low temperature SCR mechanism on 2Mn-2Cu/SAPO. 

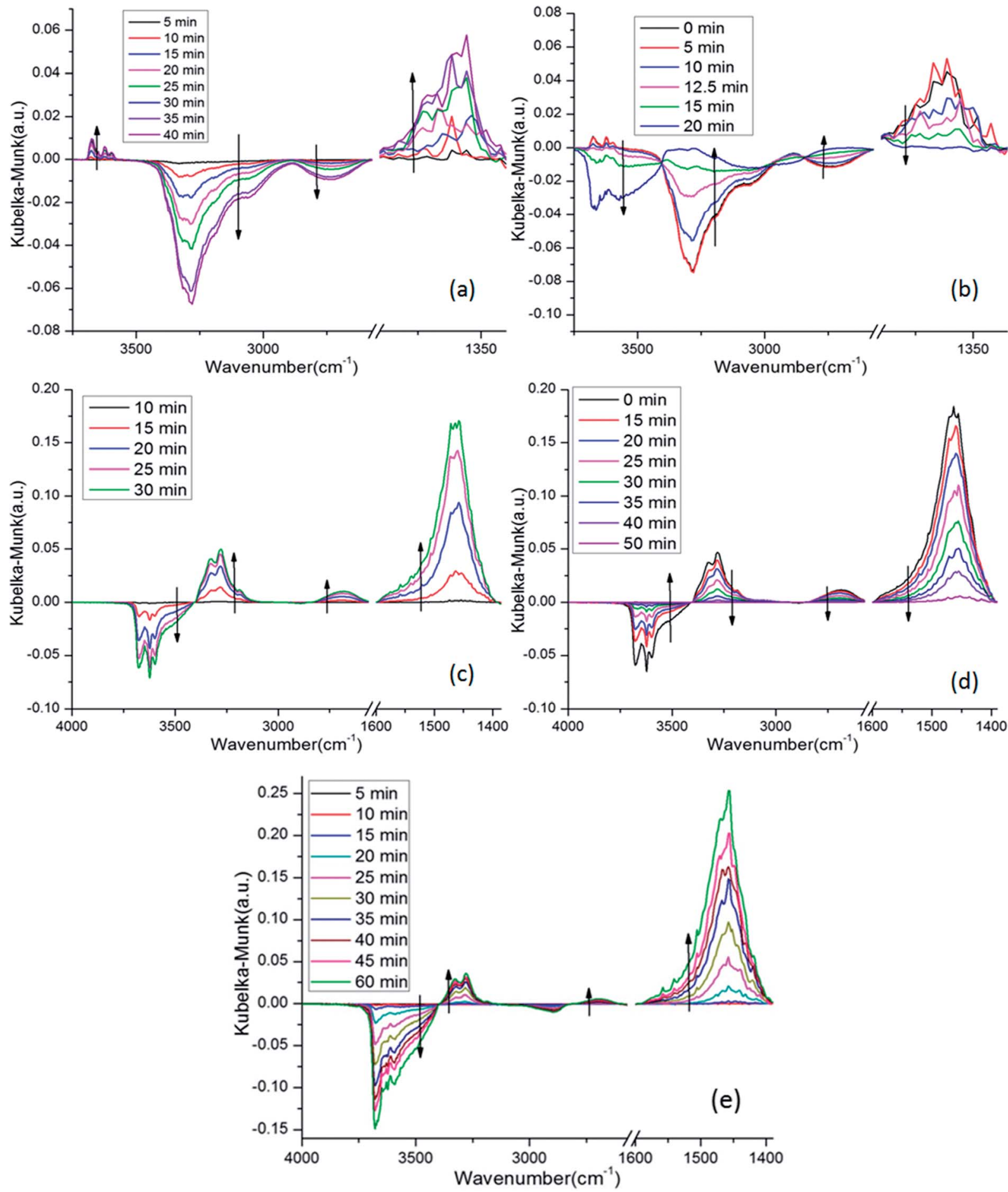

Fig. 10 DRIFTS spectra of $4 \mathrm{Mn}-2 \mathrm{Cu} / \mathrm{SAPO}$ at $150{ }^{\circ} \mathrm{C}$ exposed to gas phase of (a) $500 \mathrm{ppm} \mathrm{NO}+3 \%$ vol $\mathrm{O}_{2}+\mathrm{N}_{2}$ (balance); (b) 500 ppm NH $3+3 \%$ vol $\mathrm{O}_{2}+\mathrm{N}_{2}$ (balance) after saturation with $\mathrm{NO}$; (c) 500 ppm NH $\mathrm{NH}_{3}+3 \%$ vol $\mathrm{O}_{2}+\mathrm{N}_{2}$ (balance); (d) 500 ppm NO $+3 \%$ vol O $+\mathrm{N}_{2}$ (balance) after saturation with $\mathrm{NH}_{3}$; (e) 500 ppm NO 500 ppm NH $3+3 \%$ vol $\mathrm{O}_{2}+\mathrm{N}_{2}$ (balance).

$1600 \mathrm{~nm}$, which belongs to nitrite groups, ${ }^{32,33}$ suggesting that those NO species were nitrite groups. The negative bands at $3280 \mathrm{~cm}^{-1}$ and $2730 \mathrm{~cm}^{-1}$ might be attributed to the depletion of Brønsted base sites by the nitrite groups. Three bands at $3675 \mathrm{~cm}^{-1}, 3623 \mathrm{~cm}^{-1}$ and $3598 \mathrm{~cm}^{-1}$ could be attributed to the appearance of $\mathrm{O}-\mathrm{H}$ bond of nitrite groups $(-\mathrm{N}-\mathrm{O}-\mathrm{H})$ in different chemical environments. When $\mathrm{NH}_{3}$ was introduced into the system, as shown in Fig. 10b, the bands associated with nitrite groups decreased rapidly, indicating reaction between $\mathrm{NH}_{3}$ and NO related species.

In Fig. 10c, when $\mathrm{NH}_{3}$ was introduced into the system, the bands at $1463 \mathrm{~cm}^{-1}$ increased greatly, indicating the generation 
of $\mathrm{NH}_{3}$ species on the Brønsted acid sites, ${ }^{22}$ while the bands at $1210 \mathrm{~cm}^{-1}$ increased slightly, which was consistent with the fact that most of the acid sites on SAPO-34 were Brønsted acid sites. The negative bands at $3681 \mathrm{~cm}^{-1}, 3625 \mathrm{~cm}^{-1}$ and $3600 \mathrm{~cm}^{-1}$ were attributed to the depletion of Brønsted acid sites, which was caused by the adsorption of $\mathrm{NH}_{3}$. Specifically, the negative bands at $3681 \mathrm{~cm}^{-1}$ were assigned to the occupation of $\mathrm{P}-\mathrm{OH}$ sites by $\mathrm{NH}_{3}$. The other two bands were related to the depletion of $\mathrm{Si}-\mathrm{OH}-\mathrm{Al}$ acid sites. The band at $3147-3396 \mathrm{~cm}^{-1}$ was attributed to the $\mathrm{N}-\mathrm{H}$ stretching vibrations of $\mathrm{NH}_{4}{ }^{+} \cdot{ }^{22}$ When NO was introduced into the system, as shown in Fig. 10d, the bands related to the $\mathrm{NH}_{3}$ species decreased gradually, which was caused by the reaction between $\mathrm{NO}$ and $\mathrm{NH}_{3}$.

Fig. 10e and c are similar in that only bands related to $\mathrm{NH}_{3}$ are visible, while no other bands appeared, especially the negative bands at $2700 \mathrm{~cm}^{-1}$ and $3000-3400 \mathrm{~cm}^{-1}$ were invisible.

This was strong evidence that only the Elay-Rideal mechanism was effective on the $4 \mathrm{Mn}-2 \mathrm{Cu} / \mathrm{SAPO}$ at $150{ }^{\circ} \mathrm{C}$. Since if Langmuir-Hinshelwood mechanism was effective, the adsorbed and well activated $\mathrm{NO}$ and $\mathrm{NH}_{3}$ related species would react with each other, while the NO species not well activated would accumulated and be detectable for DRIFTS, leading to the appearance of negative bands at 2700 and $3000-3400 \mathrm{~nm}^{-1}$, as Fig. 10a and b show. Due to the fact that those peaks were not observed in Fig. 10e, all these observations lead to the exclusion of the Langmuir-Hinshelwood mechanism and the assurance of the Elay-Rideal mechanism. In the Elay-Rideal mechanism, NO molecules from gas phase directly react with the well activated $\mathrm{NH}_{3}$ species adsorbed on the surface and leave as products to gas phase with the active site left.

\section{Conclusion}

In this work, the SCR activity and physicochemical properties of $x \mathrm{Mn}-2 \mathrm{Cu} / \mathrm{SAPO}$ were investigated. The $\mathrm{H}_{2}$-TPR, UV-vis and XPS results showed that $\mathrm{Mn}^{4+}$ and $\mathrm{Mn}^{3+}$ species began to appear when manganese loading reached $2 \%$. The NO oxidation results showed that $2 \mathrm{Mn}-2 \mathrm{Cu} / \mathrm{SAPO}$ had the best NO oxidation activity, indicating that good interaction existed between copper and manganese, which was consistent with the XPS results of $\mathrm{Cu} 2 \mathrm{p}$ binding energy.

The graph of the promotion effect of manganese showed that for $2 \mathrm{Mn}-2 \mathrm{Cu} / \mathrm{SAPO}$, manganese had a good promotion effect on 2Cu/SAPO. According to $\mathrm{H}_{2}$-TPR, UV-vis, XPS and NO oxidation results, the promotion effect of manganese on $2 \mathrm{Cu} / \mathrm{SAPO}$ comes from the generation of $\mathrm{Mn}^{3+}$ and $\mathrm{Mn}^{4+}$ species. The addition of manganese increased the ratio of $\mathrm{Cu}^{2+}$. The $\mathrm{Mn}^{3+}$ and $\mathrm{Mn}^{4+}$ species might take part in the catalytic cycle and accelerate the oxidation of $\mathrm{Cu}^{+}$to $\mathrm{Cu}^{2+}$.

From the in situ DRIFTS results, the acid sites on the surface were mainly Brønsted acid sites, the main mechanism on $4 \mathrm{Mn}-$ $2 \mathrm{Cu} / \mathrm{SAPO}-34$ at low temperature was the Elay-Rideal mechanism.

\section{Conflicts of interest}

There are no conflicts to declare.

\section{Acknowledgements}

This research is sponsored by the China National Key Research and Development Program via Project No. 2016YFB0600603.

\section{References}

1 T. Boningari and P. G. Smirniotis, Impact of nitrogen oxides on the environment and human health: Mn-based materials for the $\mathrm{NO}_{x}$ abatement, Curr. Opin. Chem. Eng., 2016, 13, 133141.

2 P. G. Smirniotis, D. A. PenÄ and B. S. Uphade, LowTemperature Selective Catalytic Reduction (SCR) of NO with $\mathrm{NH}_{3}$ by Using $\mathrm{Mn}, \mathrm{Cr}$, and $\mathrm{Cu}$ Oxides Supported on Hombikat $\mathrm{TiO}_{2}$, Angew. Chem., Int. Ed., 2001, 40, 2479-2482.

3 P. R. Ettireddy, N. Ettireddy, T. Boningari, R. Pardemann and P. G. Smirniotis, Investigation of the selective catalytic reduction of nitric oxide with ammonia over $\mathrm{Mn} / \mathrm{TiO}_{2}$ catalysts through transient isotopic labeling and in situ FTIR studies, J. Catal., 2012, 292, 53-63.

4 B. Thirupathi and P. G. Smirniotis, Nickel-doped $\mathrm{Mn} / \mathrm{TiO}_{2}$ as an efficient catalyst for the low-temperature SCR of NO with $\mathrm{NH}_{3}$ : Catalytic evaluation and characterizations, J. Catal., 2012, 288, 74-83.

5 D. K. Pappas, T. Boningari, P. Boolchand and P. G. Smirniotis, Novel manganese oxide confined interweaved titania nanotubes for the low-temperature Selective Catalytic Reduction (SCR) of $\mathrm{NO}_{x}$ by $\mathrm{NH}_{3}, J$. Catal., 2016, 334, 1-13.

6 P. R. Ettireddy and A. Kotrba, Low Temperature SCR Catalysts Optimized for Cold-Start and Low-Load Engine Exhaust Conditions, SAE Technical Paper 2015-01-1026, 2015.

7 C. Wang, J. Wang, J. Wang, T. Yu, M. Shen, W. Wang and W. Li, The effect of sulfate species on the activity of $\mathrm{NH}_{3}$ SCR over Cu/SAPO-34, Appl. Catal., B, 2017, 204, 239.

8 C. Paolucci, I. Khurana, A. A. Parekh, R. Gounder, et al. Dynamic multinuclear sites formed by mobilized copper ions in $\mathrm{NO}_{x}$ selective catalytic reduction, Appl. Catal., B, 2018, 220, 161-170.

9 F. Gao, J. Kwak, J. Szanyi and C. F. Peden, Current Understanding of Cu-Exchanged Chabazite Molecular Sieves for Use as Commercial Diesel Engine DeNO $x$ Catalysts, Top. Catal., 2013, 56, 1441-1459.

10 X. Dong, J. Wang, H. Zhao and Y. Li, The promotion effect of $\mathrm{CeO}_{x}$ on Cu-SAPO-34 catalyst for selective catalytic reduction of $\mathrm{NO}_{x}$ with ammonia, Catal. Today, 2015, 258, 28-34.

11 Y. Cao, S. Zou, L. Lan, Z. Yang, H. Xu, T. Lin, M. Gong and Y. Chen, Promotional effect of Ce on Cu-SAPO-34 monolith catalyst for selective catalytic reduction of $\mathrm{NO}_{x}$ with ammonia, J. Mol. Catal. A: Chem., 2015, 398, 304-311.

12 K. Leistner, O. Mihai, K. Wijayanti, A. Kumar, K. Kamasamudram, N. W. Currier, A. Yezerets and L. Olsson, Comparison of $\mathrm{Cu} / \mathrm{BEA}, \mathrm{Cu} / \mathrm{SSZ}-13$ and $\mathrm{Cu} /$ SAPO-34 for ammonia-SCR reactions, Catal. Today, 2015, 258, 49-55.

13 L. Ma, Y. Cheng, G. Cavataio, R. W. McCabe, L. Fu and J. Li, In situ DRIFTS and temperature-programmed technology 
study on $\mathrm{NH}_{3}$-SCR of $\mathrm{NO}_{x}$ over Cu-SSZ-13 and Cu-SAPO-34 catalysts, Appl. Catal., B, 2014, 156-157, 428-437.

14 C. Pang, Y. Zhuo and Q. Weng, Mn/SAPO-34 as an efficient catalyst for the low-temperature selective catalytic reduction of $\mathrm{NO}_{x}$ with $\mathrm{NH}_{3}, R S C A d v ., 2017,7,32146-32154$.

15 G. Qi and R. T. Yang, Low-temperature selective catalytic reduction of $\mathrm{NO}$ with $\mathrm{NH}_{3}$ over iron and manganese oxides supported on titania, Appl. Catal., B, 2003, 44, 217-225.

16 D. Wang, Y. Jangjou, Y. Liu, M. K. Sharma, J. Luo, J. Li, K. Kamasamudram and W. S. Epling, A comparison of hydrothermal aging effects on $\mathrm{NH}_{3}$-SCR of $\mathrm{NO}_{x}$ over CuSSZ-13 and Cu-SAPO-34 catalysts, Appl. Catal., B, 2015, 165, 438-445.

17 D. Wang, L. Zhang, J. Li, K. Kamasamudram and W. S. Epling, $\mathrm{NH}_{3}$-SCR over $\mathrm{Cu} / \mathrm{SAPO}-34$ - Zeolite acidity and $\mathrm{Cu}$ structure changes as a function of $\mathrm{Cu}$ loading, Catal. Today, 2014, 231, 64-74.

18 D. K. Pappas, T. Boningari, P. Boolchand and P. G. Smirniotis, Novel manganese oxide confined interweaved titania nanotubes for the low-temperature Selective Catalytic Reduction (SCR) of $\mathrm{NO}_{x}$ by $\mathrm{NH}_{3}, J$. Catal., 2016, 334, 1-13.

19 D. A. Peña, B. S. Uphade and P. G. Smirniotis, $\mathrm{TiO}_{2}{ }^{-}$ supported metal oxide catalysts for low-temperature selective catalytic reduction of $\mathrm{NO}$ with $\mathrm{NH}_{3}$ : I. Evaluation and characterization of first row transition metals, $J$. Catal., 2004, 221, 421-431.

20 M. A. Zanjanchi and M. K. Rashidi, Structural charge transfer in the aluminophosphate molecular sieves by diffuse reflectance spectroscopy, Spectrochim. Acta, Part A, 1999, 55, 947-954.

21 S. Bennici, A. Gervasini, N. Ravasio and F. Zaccheria, Optimization of tailoring of $\mathrm{CuO}_{x}$ Species of silica alumina supported catalysts for the selective catalytic reduction of $\mathrm{NO}_{x}, J$. Phys. Chem. B, 2003, 107, 5168-5176.

22 J. Y. Luo, H. Oh, C. Henry and W. Epling, Effect of $\mathrm{C}_{3} \mathrm{H}_{6}$ on selective catalytic reduction of $\mathrm{NO}_{x}$ by $\mathrm{NH}_{3}$ over a Cu/ zeolite catalyst: A mechanistic study, Appl. Catal., B, 2012, 123-124, 296-305.

23 S. A. Yashnik, Z. R. Ismagilov and V. F. Anufrienko, Catalytic properties and electronic structure of copper ions in $\mathrm{Cu}$ ZSM-5, Catal. Today, 2005, 110, 310-322.

24 O. P. Taran, S. A. Yashnik, A. B. Ayusheev, A. S. Piskun, R. V. Prihod'ko, Z. R. Ismagilov, V. V. Goncharuk and
V. N. Parmon, Cu-containing MFI zeolites as catalysts for wet peroxide oxidation of formic acid as model organic contaminant, Appl. Catal., B, 2013, 140-141, 506-515.

25 S. Bennici, A. Gervasini, N. Ravasio and F. Zaccheria, Optimization of tailoring of $\mathrm{CuO}_{x}$ species of silica alumina supported catalysts for the selective catalytic reduction of $\mathrm{NO}_{x}$, J. Phys. Chem. B, 2003, 107, 5168-5176.

26 T. Kharlamova, G. Mamontov, M. Salaev, V. Zaikovskii, G. Popova, V. Sobolev, A. Knyazev and O. Vodyankina, Structural charge transfer in the aluminophosphate molecular sieves by diffuse reflectance spectroscopy, Appl. Catal., A, 2013, 467, 519-529.

27 Q. Tang, S. Hu, Y. Chen, Z. Guo, Y. Hu, Y. Chen and Y. Yang, Highly dispersed manganese oxide catalysts grafted on SBA15: synthesis, characterization and catalytic application in trans-stilbene epoxidation, Microporous Mesoporous Mater., 2010, 132, 501-509.

28 I. Spassova, T. Tsontcheva, N. Velichkova, M. Khristova and D. Nihtianova, Catalytic reduction of NO with decomposed methanol on alumina-supported Mn-Ce catalysts, $J$. Colloid Interface Sci., 2012, 374, 267-277.

29 Z. Qu, Y. Bu, Y. Qin, Y. Wang and Q. Fu, The improved reactivity of manganese catalysts by $\mathrm{Ag}$ in catalytic oxidation of toluene, Appl. Catal., B, 2013, 132-133, 353-362.

30 T. Boningari, P. R. Ettireddy, A. Somogyvari, Y. Liu, A. Vorontsov, C. A. McDonald and P. G. Smirniotis, Influence of elevated surface texture hydrated titania on Ce-doped $\mathrm{Mn} / \mathrm{TiO}_{2}$ catalysts for the low-temperature SCR of $\mathrm{NO}_{x}$ under oxygen-rich conditions, J. Catal., 2015, 325, 145-155.

31 T. Boningari, D. K. Pappas, P. R. Ettireddy, A. Kotrba and P. G. Smirniotis, Influence of $\mathrm{SiO}_{2}$ on $\mathrm{M} / \mathrm{TiO}_{2}(\mathrm{M}=\mathrm{Cu}$, $\mathrm{Mn}$, and Ce) Formulations for Low-Temperature Selective Catalytic Reduction of $\mathrm{NO}_{x}$ with $\mathrm{NH}_{3}$ : Surface Properties and Key Components in Relation to the Activity of $\mathrm{NO}_{x}$ Reduction, Ind. Eng. Chem. Res., 2015, 54, 2261-2273.

32 C. Lamberti, S. Bordiga, M. Salvalaggio, G. Spoto and A. Zecchina, XAFS, IR, and UV-vis Study of the $\mathrm{Cu}^{\mathrm{I}}$ Environment in Cu $\mathrm{Cu}^{\mathrm{I}}$ ZSM-5, J. Phys. Chem. B, 1997, 101, 344-360.

$33 \mathrm{M}$. Iwasaki and $\mathrm{H}$. Shinjoh, $\mathrm{NO}$ evolution reaction with $\mathrm{NO}_{2}$ adsorption over Fe/ZSM-5: in situ FT-IR observation and relationships with Fe sites, J. Catal., 2010, 273, 29-38. 